\title{
Temporal characteristics of atmospheric ammonia and nitrogen dioxide over China based on emission data, satellite observations and atmospheric transport modeling since 1980
}

\author{
Lei Liu ${ }^{1}$, Xiuying Zhang ${ }^{1}$, Wen $\mathrm{Xu}^{2}$, Xuejun $\mathrm{Liu}^{2}$, Yi Li ${ }^{3}$, Xuehe Lu ${ }^{1}$, Yuehan Zhang ${ }^{4}$, and Wuting Zhang ${ }^{1,5}$ \\ ${ }^{1}$ Jiangsu Provincial Key Laboratory of Geographic Information Science and Technology, International Institute for Earth \\ System Science, Nanjing University, Nanjing 210023, China \\ ${ }^{2}$ College of Resources and Environmental Sciences, Centre for Resources, Environment and Food Security, Key Lab of \\ Plant-Soil Interactions of MOE, China Agricultural University, Beijing 100193, China \\ ${ }^{3}$ Air Quality Division, Arizona Department of Environmental Quality, Phoenix, AZ 85007, USA \\ ${ }^{4}$ School of Atmospheric Sciences, Nanjing University, Nanjing, China \\ ${ }^{5}$ Jiangsu Center for Collaborative Innovation in Geographical Information Resource Development and Application, \\ Nanjing 210023, China
}

Correspondence to: Xiuying Zhang (lzhxy77@163.com)

Received: 3 February 2017 - Discussion started: 21 March 2017

Revised: 16 June 2017 - Accepted: 10 July 2017 - Published: 7 August 2017

\begin{abstract}
China is experiencing intense air pollution caused in large part by anthropogenic emissions of reactive nitrogen $\left(\mathrm{N}_{\mathrm{r}}\right)$. Atmospheric ammonia $\left(\mathrm{NH}_{3}\right)$ and nitrogen dioxide $\left(\mathrm{NO}_{2}\right)$ are the most important precursors for $\mathrm{N}_{\mathrm{r}}$ compounds (including $\mathrm{N}_{2} \mathrm{O}_{5}, \mathrm{HNO}_{3}$, $\mathrm{HONO}$ and particulate $\mathrm{NO}_{3}^{-}$and $\mathrm{NH}_{4}^{+}$) in the atmosphere. Understanding the changes in $\mathrm{NH}_{3}$ and $\mathrm{NO}_{2}$ has important implications for the regulation of anthropogenic $\mathrm{N}_{\mathrm{r}}$ emissions and is a requirement for assessing the consequence of environmental impacts. We conducted the temporal trend analysis of atmospheric $\mathrm{NH}_{3}$ and $\mathrm{NO}_{2}$ on a national scale since 1980 based on emission data (during 1980-2010), satellite observation (for $\mathrm{NH}_{3}$ since 2008 and for $\mathrm{NO}_{2}$ since 2005) and atmospheric chemistry transport modeling (during 2008-2015).

Based on the emission data, during 1980-2010, significant continuous increasing trends in both $\mathrm{NH}_{3}$ and $\mathrm{NO}_{x}$ were observed in REAS (Regional Emission inventory in Asia, for $\mathrm{NH}_{3} 0.17$ and for $\mathrm{NO}_{x} 0.16 \mathrm{~kg} \mathrm{Nha}^{-1} \mathrm{yr}^{-2}$ ) and EDGAR (Emissions Database for Global Atmospheric Research, for $\mathrm{NH}_{3} 0.24$ and for $\mathrm{NO}_{x} 0.17 \mathrm{~kg} \mathrm{~N} \mathrm{ha}^{-1} \mathrm{yr}^{-2}$ ) over China. Based on the satellite data and atmospheric chemistry transport model (CTM) MOZART-4 (Model for Ozone and Related chemical Tracers, version 4), the $\mathrm{NO}_{2}$ columns over China increased significantly from 2005 to 2011 and
\end{abstract}

then decreased significantly from 2011 to 2015; the satelliteretrieved $\mathrm{NH}_{3}$ columns from 2008 to 2014 increased at a rate of $2.37 \% \mathrm{yr}^{-1}$. The decrease in $\mathrm{NO}_{2}$ columns since 2011 may result from more stringent strategies taken to control $\mathrm{NO}_{x}$ emissions during the 12th Five Year Plan, while no control policy has focused on $\mathrm{NH}_{3}$ emissions. Our findings provided an overall insight into the temporal trends of both $\mathrm{NO}_{2}$ and $\mathrm{NH}_{3}$ since 1980 based on emission data, satellite observations and atmospheric transport modeling. These findings can provide a scientific background for policy makers that are attempting to control atmospheric pollution in China. Moreover, the multiple datasets used in this study have implications for estimating long-term $\mathrm{N}_{\mathrm{r}}$ deposition datasets to assess its impact on soil, forest, water and greenhouse balance.

\section{Introduction}

Reactive nitrogen $\left(\mathrm{N}_{\mathrm{r}}\right)$ emissions have increased significantly in China due to anthropogenic activities such as increased combustion of fossil fuels, over-fertilization and high stocking rates of farm animals (Canfield et al., 2010; Galloway et al., 2008; Liu et al., 2013). Elevated $\mathrm{N}_{\mathrm{r}}$ in the environment has led to a series of effects on climate change and 
ecosystems, e.g., biodiversity loss, stratospheric ozone depletion, air pollution, freshwater eutrophication, the potential alteration of global temperature, drinking water contamination, dead zones in coastal ecosystems and grassland seed bank depletion (Basto et al., 2015; Lan et al., 2015; Shi et al., 2015). Atmospheric reactive $\mathrm{N}$ emissions are dominated by nitrogen oxides $\left(\mathrm{NO}_{x}=\mathrm{NO}+\mathrm{NO}_{2}\right)$ and ammonia $\left(\mathrm{NH}_{3}\right.$; Li et al., 2016; Galloway et al., 2004). Atmospheric $\mathrm{NO}_{2}$ and $\mathrm{NH}_{3}$ are the most important precursors for $\mathrm{N}_{\mathrm{r}}$ compounds including $\mathrm{N}_{2} \mathrm{O}_{5}, \mathrm{HNO}_{3}$, $\mathrm{HONO}$ and particulate $\mathrm{NO}_{3}^{-}$and $\mathrm{NH}_{4}^{+}$ in the atmosphere (Xu et al., 2015; Pan et al., 2012). Therefore, an understanding of both the spatial and temporal patterns of $\mathrm{NO}_{2}$ and $\mathrm{NH}_{3}$ is essential for evaluating $\mathrm{N}$-enriched environmental effects, and can provide the scientific background for $\mathrm{N}$ pollution mitigation.

To investigate the spatial and temporal variations in atmospheric $\mathrm{NO}_{2}$ and $\mathrm{NH}_{3}$, ground measurements are acknowledged to be an effective way of monitoring the accurate concentrations of $\mathrm{NO}_{2}$ and $\mathrm{NH}_{3}$ (Xu et al., 2015; Pan et al., 2012; Meng et al., 2010). Ground measurements of $\mathrm{NO}_{2}$ concentrations in China, including about 500 stations in 74 cities, have been monitored and reported to the public since January 2013 (Xie et al., 2015). By the end of 2013, this network was extended with hourly $\mathrm{NO}_{2}$ concentrations from more than 850 stations in 161 cities. However, there are fewer $\mathrm{NH}_{3}$ measurements across China than $\mathrm{NO}_{2}$ measurements. The China Agricultural University has organized a nationwide nitrogen deposition monitoring network (NNDMN) since 2010, consisting of 43 monitoring sites covering urban, rural (cropland) and background (coastal, forest and grassland) areas across China (Xu et al., 2015; Liu et al., 2011). $\mathrm{Xu}$ et al. (2015) reported the ground $\mathrm{NH}_{3}$ concentrations throughout China for the first time, providing great potential to understand the ground $\mathrm{NH}_{3}$ concentrations on a national scale. Other networks include the Chinese Ecosystem Research Network (CERN) which was established in 1988, including 40 field stations (Fu et al., 2010). However, to our knowledge, there are no detailed reports about ground $\mathrm{NH}_{3}$ concentrations from CERN on a national scale. In addition, four Chinese cities (Xiamen, Xi' an, Chongqing and Zhuhai) have joined the Acid Deposition Monitoring Network in East Asia (EANET) since 1999. However, only one site (Hongwen, Xiamen) in EANET measured the ground $\mathrm{NH}_{3}$ concentrations, and the data from it are not continuous. Finally, ground $\mathrm{NH}_{3}$ concentrations at 10 sites in northern China from 2007 to 2010 have been reported by Pan et al. (2012). All of the aboveground measurements provide the potential to understand $\mathrm{NH}_{3}$ and $\mathrm{NO}_{2}$ concentrations on a regional scale. However, there is limited information on the spatial and temporal variations in $\mathrm{NH}_{3}$ and $\mathrm{NO}_{2}$ in the atmosphere across China. This is due to the limited observation sites and monitoring period, as well as given the uneven distribution of the monitoring sites. Importantly, atmospheric $\mathrm{NH}_{3}$ and $\mathrm{NO}_{2}$ monitoring based on ground-based local sites may have limited spatial representativeness of the regional scale as both
$\mathrm{NH}_{3}$ and $\mathrm{NO}_{2}$ are highly variable in time and space (Clarisse et al., 2009; Wichink Kruit et al., 2012; Boersma et al., 2007).

In order to complement ground-based measurements, satellite observation of $\mathrm{NH}_{3}$ and $\mathrm{NO}_{2}$ is a welcome addition for analyzing the recent trends of $\mathrm{NH}_{3}$ and $\mathrm{NO}_{2}$ in the atmosphere. Satellite remote sensing offers an opportunity to monitor atmospheric $\mathrm{NH}_{3}$ and $\mathrm{NO}_{2}$ with high temporal and spatial resolutions (Warner et al., 2017; Li et al., 2017). $\mathrm{NO}_{2}$ was measured by multiple space-based instruments, including the Global Ozone Monitoring Experiment (GOME), SCanning Imaging Absorption SpectroMeter for Atmospheric CHartographY (SCIAMACHY), Ozone Monitoring Instrument (OMI) and Global Ozone Monitoring Experiment-2 (GOME-2). The OMI $\mathrm{NO}_{2}$ provides the best horizontal resolution $(13 \mathrm{~km} \times 24 \mathrm{~km})$ among instruments in its class and near-global daily coverage (Boersma et al., 2007). OMI observations have been widely applied in environmental-related studies and for the support of emission control policy (Russell et al., 2012; Zhao and Wang, 2009; Castellanos et al., 2015; Lamsal et al., 2015; F. Liu et al., 2016; Foy et al., 2016). First measurements of $\mathrm{NH}_{3}$ from space were reported over Beijing and San Diego areas with the Tropospheric Emission Spectrometer (TES; Beer et al., 2008) and in fire plumes in Greece with the Infrared Atmospheric Sounding Interferometer (IASI; Coheur et al., 2009). The first global map of $\mathrm{NH}_{3}$ was created from IASI measurements by correlating the observed brightness temperature differences to $\mathrm{NH}_{3}$ columns using the averaged datasets in 2008 (Clarisse et al., 2009). Shortly after that, many studies focused on developing techniques to gain more reliable $\mathrm{NH}_{3}$ columns (Whitburn et al., 2016a; Van Damme et al., 2014a), validating the retrieved $\mathrm{NH}_{3}$ columns using the ground measurements (Van Damme et al., 2015; Dammers et al., 2016) and comparing the data with the results of the atmospheric chemistry transport models (Van Damme et al., 2014b; Whitburn et al., 2016a), and the estimated $\mathrm{NH}_{3}$ columns obtained from Fourier transform infrared spectroscopy (FTIR; Dammers et al., 2016). The retrieval algorithm of obtaining IASI $\mathrm{NH}_{3}$ columns was based on the method described in Whitburn et al. (2016a). Two main steps were performed to derive the $\mathrm{NH}_{3}$ columns from the satellite measurements. First, derive the spectral hyperspectral range index (HRI) based on each IASI observations (Walker et al., 2011; Van Damme et al., 2014a). Second, convert HRI to $\mathrm{NH}_{3}$ columns based on a constructed neural network with input parameters including vertical $\mathrm{NH}_{3}$ profile, satellite viewing angle, surface temperature and so on (Whitburn et al., 2016a). The progress made in satellite techniques provides a possibility for understanding both the spatial and temporal variations in $\mathrm{NH}_{3}$ and $\mathrm{NO}_{2}$ in the atmosphere.

In addition to satellite observations, the emission data are also very important for investigating the temporal trends of $\mathrm{NH}_{3}$ and $\mathrm{NO}_{2}$ such as the IIASA inventory (Cofala et al., 2007), EDGAR (Emission Database for Global Atmospheric Research, RAINS-Asia (Regional Air Pollution Information 
and Simulation) and Asia REAS (FRCGC, 2007). REAS is considered the first inventory to integrate historical, current and future emissions data for Asia based on a consistent methodology (Ohara et al., 2007), and EDGAR is the global emission data with 0.1 by 0.1 grid, which has the highest spatial resolution among different datasets mentioned above. Thus, REAS and EDGAR are used to analyze the historical trends of $\mathrm{NH}_{3}$ and $\mathrm{NO}_{2}$ during 1980-2010 in this study. Based on the EDGAR emission data, a widely used atmospheric transport model named as the Model for Ozone and Related chemical Tracers, version 4 (MOZART-4) was also used to model the temporal trend of $\mathrm{NH}_{3}$ and $\mathrm{NO}_{2}$ columns during 2008-2015 in comparison with the temporal trends of $\mathrm{NH}_{3}$ and $\mathrm{NO}_{2}$ columns measured by satellite instruments.

We aim at getting an overall insight into the temporal trends of both $\mathrm{NO}_{2}$ and $\mathrm{NH}_{3}$ since 1980 based on the multiple datasets including the emission data, satellite observations and atmospheric transport modeling. We herein show the Chinese national trend of REAS and EDGAR $\mathrm{NH}_{3}$ and $\mathrm{NO}_{x}$ emission data during 1980-2010, satellite-retrieved $\mathrm{NH}_{3}$ and $\mathrm{NO}_{2}$ columns during 2008-2015 and 2005-2015, respectively, and atmospheric transport chemistry modeling of $\mathrm{NH}_{3}$ and $\mathrm{NO}_{2}$ columns during 2008-2015. It should be noted here that the satellite $\mathrm{NH}_{3}$ columns were retrieved from the IASI, and can only be obtained since 2008. It is beneficial to analyze the temporal variations in both $\mathrm{NH}_{3}$ and $\mathrm{NO}_{2}$, hence providing a scientific basis for policy makers to reduce $\mathrm{N}$-enriched environmental pollution in China.

\section{Materials and methods}

\section{1 $\mathrm{NH}_{3}$ and $\mathrm{NO}_{2}$ emissions}

We examined the REAS (Regional Emission Inventory in Asia) emission inventory dataset for Asia with $0.5^{\circ} \times 0.5^{\circ}$ resolution for the period 1980-2010 and analyzed the temporal trends of $\mathrm{NO}_{x}$ and $\mathrm{NH}_{3}$ over China. REAS v1.1 is believed to be the first inventory of integrating past, present and future dataset in Asia based on a consistent methodology. The REAS datasets have been validated by several emissions, and denote agreement with the recent growth status in Chinese emissions (Ohara et al., 2007). We also collected $\mathrm{NO}_{x}$ and $\mathrm{NH}_{3}$ emission data from EDGAR (Emissions Database for Global Atmospheric Research) v4.3.1, which was developed by the Netherlands Environmental Assessment Agency and European Commission Joint Research Centre (Jgj et al., 2002). The EDGAR emissions are calculated on the basis of a point emissions inventory conducted by the International Energy Agency. EDGAR also covers a long time period (1980-2010), with the highest spatial resolution globally $\left(0.1^{\circ} \times 0.1^{\circ}\right.$; http://edgar.jrc.ec.europa.eu/ overview.php?v=431).

\subsection{Satellite observations}

IASI is a passive remote-sensing instrument operating in nadir mode that measures the infrared radiation emitted by the Earth's surface and the atmosphere (Clarisse et al., 2009). It covers the entire globe twice a day, crossing the Equator at a mean solar local time of 09:30 and 21:30 and has an elliptical footprint of 12 by $12 \mathrm{~km}$ up to 20 by $39 \mathrm{~km}$ depending on the satellite-viewing angle. In this study we use daytime satellite observations as these are more sensitive to $\mathrm{NH}_{3}$ and are associated with a large positive thermal contrast and a significant amount of $\mathrm{NH}_{3}$ (Van Damme et al., 2014a; Whitburn et al., 2016a). The availability of measurements is mainly driven by the cloud coverage as only observations with cloud coverage lower than $25 \%$ are processed to be a good compromise between the number of data kept for the analysis and the bias due to the effect of clouds. As the quantity of daily data is not always sufficient to obtain meaningful distributions (due to cloud cover or the availability of the temperature profiles from the EUMETSAT operational processing chain; Van Damme et al., 2014a), it is more appropriate to consider monthly or yearly averages for this trend analysis. We consider IASI observations with a relative error below $100 \%$ or an absolute error below $5 \times 10^{15}$ molec $\mathrm{cm}^{-2}$ for analysis over China. For the error, the filtering depends on the use of the data. For this, low columns typical for background conditions with a large relative error but a small absolute error are also taken into account. For other applications, such as comparing with ground measurements, we would recommend to use a threshold of $75 \%$ or even $100 \%$ relative error. We gained the data upon request from the Atmospheric Spectroscopy Group at Université Libre De Bruxelles (http://www.ulb.ac.be/cpm/atmosphere.html). These data can be gridded on $0.1^{\circ}$ latitude $\times 0.1^{\circ}$ longitude (Dammers et al., 2016), $0.25^{\circ}$ latitude $\times 0.25^{\circ}$ longitude (Whitburn et al., 2016a) and $0.5^{\circ}$ latitude $\times 0.5^{\circ}$ longitude (Whitburn et al., 2016b) or even coarser resolutions depending on the usage of the data. For IASI $\mathrm{NH}_{3}$, we firstly divided China into a $0.5^{\circ}$ latitude $\times 0.5^{\circ}$ longitude grid. For each grid cell, we calculated the monthly arithmetic mean by averaging the daily values with observations points within the grid cell. Similarly, we calculated the annual arithmetic mean by averaging the daily values with observations points within the grid cell over the whole year.

The $\mathrm{NO}_{2}$ columns are obtained from the OMI instrument on NASA's EOS Aura satellite globally every day. We used the generated products by the project "Derivation of Ozone Monitoring Instrument tropospheric $\mathrm{NO}_{2}$ in near-real time" (DOMINO) to analyze the temporal trends of $\mathrm{NO}_{2}$ columns over China. In DOMINO products, only the observations with a cloud radiance fraction below 0.5 were processed for analysis. The retrieval algorithm is described in detail in the previous work (Boersma et al., 2007) and recent updates can be found in the DOMINO Product Specification Document (http://www.temis.nl/docs/OMI_NO2_HE5_ 
1.0.2.pdf). We used tropospheric $\mathrm{NO}_{2}$ retrievals from the DOMINO algorithm $v 2.0$. The retrieval quality of $\mathrm{NO}_{2}$ products is strongly dependent on different aspects of air mass factors, such as radiative transfer calculations, terrain heights and surface albedo. The OMI v2.0 data were mainly improved by more realistic atmospheric profile parameters, and include more surface albedo and surface pressure reference points than before (Boersma et al., 2011, 2016). The DOMINO $\mathrm{NO}_{2}$ datasets are available from http://www.temis. nl/airpollution/no2.html. We should state in particular that we used directly the DOMINO v2.0 products of monthly means from 2005 to 2015 over China for the trend analysis. The DOMINO $\mathrm{NO}_{2}$ columns were gridded at a resolution of $0.125^{\circ}$ latitude $\times 0.125^{\circ}$ longitude grid globally, which has been widely used for scientific applications (Ma et al., 2013; Ialongo et al., 2016; Castellanos et al., 2015).

To illustrate measurement availability, we presented here some measurement statistics. A total number of cloud-free daytime observations as characterized by the operational IASI processor by year were retrieved in China during 20082015 for $\mathrm{NH}_{3}$ (Fig. 1b). We retrieved more observation numbers after 2010 than those during 2008-2009. In 2010, the update of the improved air temperature profiles, cloud properties products and cloud detection, which are important for calculating the thermal contrast, increased the quality of retrieval (Van Damme et al., 2014a, b). In September 2014, there was another update of the air temperature profiles, cloud properties products and cloud detection for calculating the thermal contrast. The version of IASI $\mathrm{NH}_{3}$ columns used in the present work was based on the method described in Whitburn et al. (2016a). We did not use the IASI $\mathrm{NH}_{3}$ after September 30 in 2014 for the trend analysis because an update of the input meteorological data on 30 September 2014 has caused a substantial increase in the retrieved atmospheric $\mathrm{NH}_{3}$ columns. For the updates of the IASI-NH data, the reader can refer to Van Damme et al. (2014a, b), and Whitburn et al. (2016a). The monthly observation numbers are also presented in Fig. 1a, showing that spring (March, April and May), summer (June, July and August), autumn (September, October and November) and winter (December, January and February) months represent 29, 26, 23 and $21 \%$, respectively. Compared with large variations in observation numbers for $\mathrm{NH}_{3}$, the observation numbers for $\mathrm{NO}_{2}$ varied less by year; the winter season had the least, while other seasons varied little.

\subsection{Atmospheric transport chemistry model}

Atmospheric transport chemistry models are also of central importance in modeling the tropospheric $\mathrm{NO}_{2}$ and $\mathrm{NH}_{3}$. We applied the widely used atmospheric global atmospheric transport chemistry model MOZART-4 to simulate the tropospheric $\mathrm{NO}_{2}$ and $\mathrm{NH}_{3}$ columns during 2008-2015 in accordance with the time period of IASI $\mathrm{NH}_{3}$ measurements.
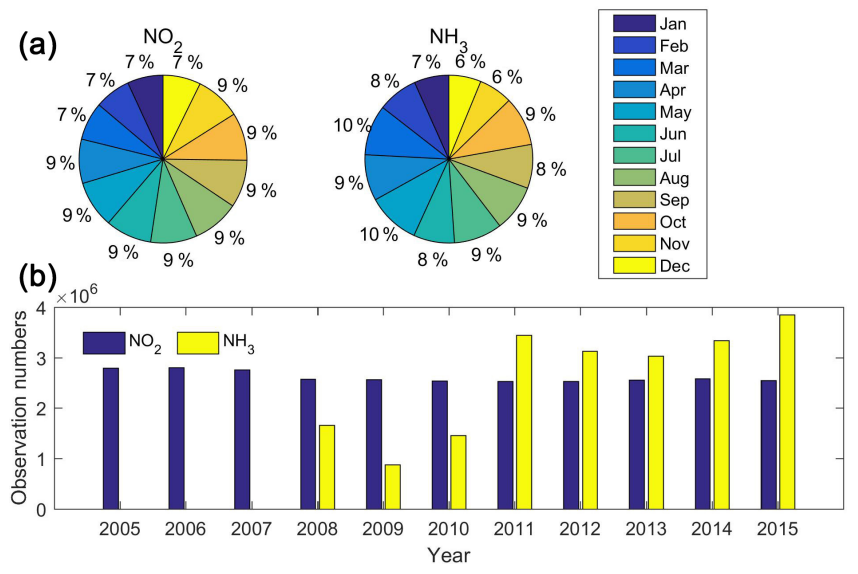

Figure 1. The satellite-derived observation numbers for $\mathrm{NO}_{2}$ and $\mathrm{NH}_{3}$. Panel (a) shows the percentages of observations in each month in 2010 for $\mathrm{NO}_{2}$ and in 2015 for $\mathrm{NH}_{3}$ and (b) represents the total observation numbers for $\mathrm{NO}_{2}$ and $\mathrm{NH}_{3}$ over China. Notably, the $\mathrm{NO}_{2}$ observation numbers were gained from DOMINO products with a cloud radiance fraction below 0.5 , while the IASI observations with a relative error below $100 \%$ or an absolute error below $5 \times 10^{15}$ molec $\mathrm{cm}^{-2}$ were processed for analysis over China.

The MOZART-4 model is driven by the meteorological data from the NASA Goddard Earth Observing System Model, version 5 (GEOS-5), at a resolution of $1.9^{\circ}$ latitude $\times 2.5^{\circ}$ longitude spatially. The emission data applied for driving the simulations are based on the updated EDGAR emission inventories. Twelve bulk aerosol compounds, 39 photolysis, 85 gas species and 157 gas-phase reactions were integrated in MOZART-4. The chemical mechanism on $\mathrm{N}$ compounds including the $\mathrm{NO}_{2}, \mathrm{NH}_{3}$ and aerosols are detailedly integrated to MOZART-4, which is considered to be suitable for tropospheric chemical compositions (Emmons et al., 2010; Pfister et al., 2008; Sahu et al., 2013). The output data used in the current work temporally vary $6 \mathrm{~h}$ every day, which were available upon request from Louisa Emmons at the National Center for Atmospheric Research (NCAR). The monthly means of $\mathrm{NO}_{2}$ and $\mathrm{NH}_{3}$ columns were averaged by the daily data, and then used for the trend analysis over China. For more details about MOZART-4, the reader should refer to previous studies (Emmons et al., 2010; Brasseur et al., 1998; Beig and Singh, 2007).

\section{Results and discussion}

\section{1 $\mathrm{NH}_{3}$ and $\mathrm{NO}_{2}$ emissions during 1980-2010}

We conducted the temporal analysis of $\mathrm{NH}_{3}$ and $\mathrm{NO}_{x}$ emissions since 1980 based on REAS and EDGAR. Significant continuous increasing trends in both $\mathrm{NH}_{3}$ and $\mathrm{NO}_{x}$ were observed from REAS (for $\mathrm{NH}_{3} 0.17$ and for $\mathrm{NO}_{x}$ $0.16 \mathrm{~kg} \mathrm{Nha}^{-1} \mathrm{yr}^{-2}$ ) and EDGAR (for $\mathrm{NH}_{3} 0.24$ and for 
$\mathrm{NO}_{x} \quad 0.17 \mathrm{~kg} \mathrm{Nha}^{-1} \mathrm{yr}^{-2}$ ) over China (Fig. 2). We found a relatively consistent increase in $\mathrm{NO}_{x}$ emission from EDGAR and REAS over China, i.e., $0.17 \mathrm{~kg} \mathrm{Nha}^{-1} \mathrm{yr}^{-2}$ vs. $0.16 \mathrm{~kg} \mathrm{Nha}^{-1} \mathrm{yr}^{-2}$, but inconsistency in the magnitude of $\mathrm{NH}_{3}$ emissions from EDGAR and REAS over China, i.e., $0.24 \mathrm{~kg} \mathrm{Nha}^{-1} \mathrm{yr}^{-2}$ vs. $0.17 \mathrm{~kg} \mathrm{Nha}^{-1} \mathrm{yr}^{-2}$. The increase rate in $\mathrm{NH}_{3}$ emissions over China from EDGAR was much higher than that from REAS, indicating that the magnitude of increase trend in $\mathrm{NH}_{3}$ over China remains a debate, although their thread values (the slope in Fig. 2) of $0.24 \mathrm{~kg} \mathrm{Nha}^{-1} \mathrm{yr}^{-2}$ (EDGAR) vs. $0.17 \mathrm{~kg} \mathrm{Nha}^{-1} \mathrm{yr}^{-2}$ (REAS) both reflected a continuous increasing trend (in this regard they are consistent). It implies that the $\mathrm{NH}_{3}$ emissions are indeed increasing during 1980-2010. We also conducted a simple correlation analysis of the $\mathrm{NH}_{3}$ (Fig. 2a) and $\mathrm{NO}_{x}$ (Fig. 2b) from REAS and EDGAR, showing agreement in the magnitude (slope $=1.06)$ and temporal trend $\left(R^{2}=0.96\right)$ for $\mathrm{NO}_{x}$, but with some inconsistency in the increase rate (slope $=1.33$ ) for $\mathrm{NH}_{3}$.

The discrepancy in the magnitude of $\mathrm{NH}_{3}$ increase rate from REAS and EDGAR $\left(0.24 \mathrm{~kg} \mathrm{Nha}^{-1} \mathrm{yr}^{-2}\right.$ vs. $0.17 \mathrm{~kg} \mathrm{~N} \mathrm{ha}^{-1} \mathrm{yr}^{-2}$ ) in China since 1980 may be caused by the different emission factors considered for estimating $\mathrm{NH}_{3}$ emissions. The EDGAR v4.3.1 $\mathrm{NH}_{3}$ emissions were calculated based on a variety of sectors, including agriculture, shipping, waste solid and wastewater, energy for buildings, process emissions during production and application, power industry, oil refineries, transformation industry, combustion for manufacturing, road transportation, railways, pipelines and off-road transport, while the REAS v1.1 $\mathrm{NH}_{3}$ emissions focused mainly on agriculture sources (i.e., manure management of livestock and fertilizer application; Crippa et al., 2016; Ohara et al., 2007). Moreover, the fundamental methodology on estimating the REAS v1.1 $\mathrm{NH}_{3}$ emissions did not consider the seasonal agricultural variations compared with that of EDGAR v4.3.1 $\mathrm{NH}_{3}$ emissions (Kurokawa et al., 2013), and the removal efficiency (as a key element to estimate $\mathrm{NH}_{3}$ emissions) was also reported to be much higher in REAS v1.1 than in EDGAR v4.3.1 (Kurokawa et al., 2013).

A previous study (Liu et al., 2013) summarized published data on the national anthropogenic $\mathrm{NH}_{3}$ and $\mathrm{NO}_{x}$ emissions with multiple periods in China (Wang et al., 2009; Wang et al., 1997; Streets et al., 2003; Klimont et al., 2001; Sun and Wang, 1997; Olivier et al., 1998; FRCGC, 2007) and also analyzed the temporal pattern of $\mathrm{NH}_{3}$ emissions. Their results showed that the $\mathrm{NH}_{3}$ emissions had increased at an annual average rate of $0.32 \mathrm{Tg} \mathrm{N} \mathrm{yr}^{-2}$ (about $0.33 \mathrm{~kg} \mathrm{Nha}^{-1} \mathrm{yr}^{-2}$ ). The increase rate of $\mathrm{NH}_{3}$ emissions $\left(0.33 \mathrm{~kg} \mathrm{Nha}^{-1} \mathrm{yr}^{-2}\right)$ by Liu et al. (2013) was double that in REAS $\left(0.17 \mathrm{~kg} \mathrm{Nha}^{-1} \mathrm{yr}^{-2}\right)$, implying that the $\mathrm{NH}_{3}$ increase rate in China is still an open question and should be further studied.
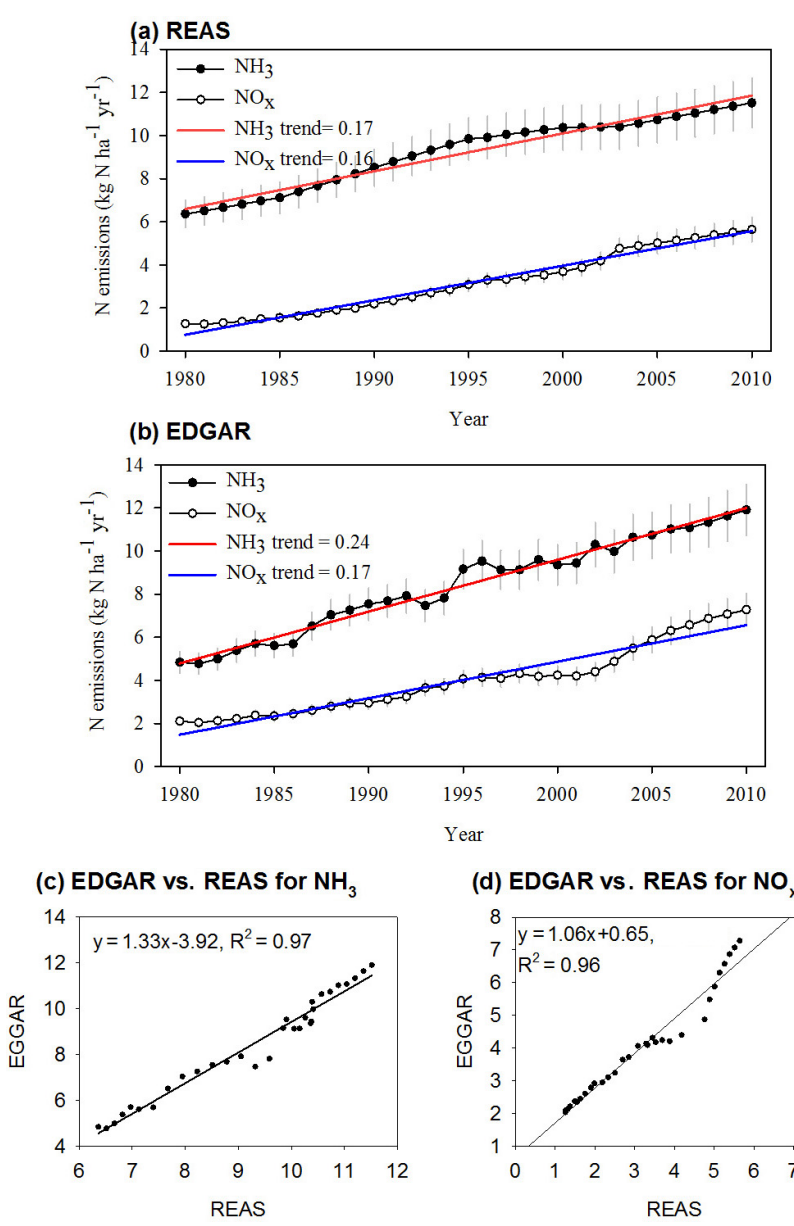

(d) EDGAR vs. REAS for $\mathrm{NO}_{\mathrm{x}}$

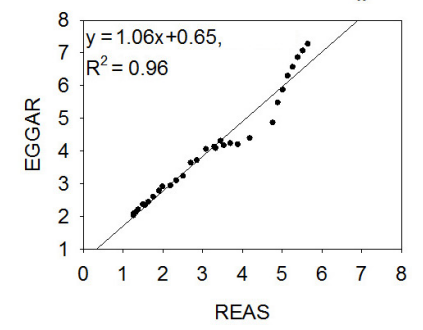

Figure 2. The $\mathrm{NO}_{2}$ and $\mathrm{NH}_{3}$ emissions over China. Panel (a) shows the $\mathrm{NO}_{2}$ and $\mathrm{NH}_{3}$ emissions over China from 1980 to 2010 from REAS, (b) represents the $\mathrm{NO}_{2}$ and $\mathrm{NH}_{3}$ emissions over China from 1980 to 2010 from EDGAR, (c) demonstrates the relationship of $\mathrm{NO}_{2}$ emissions over China from REAS and EDGAR and (d) shows the relationship of $\mathrm{NH}_{3}$ emissions over China from REAS and EDGAR.

\subsection{Satellite $\mathrm{NH}_{3}$ and $\mathrm{NO}_{2}$ over China in the recent decade}

\subsubsection{Temporal trends}

We referred to the method of a previous study (Russell et al., 2012) to conduct the temporal trend analysis by calculating the average values during cold months (OctoberMarch) and warm months (April-September), respectively. We herein concentrated more on the temporal analysis of satellite observations during warm months because of the relatively lower uncertainty in comparison with that during cold months. Figure 3 shows the temporal trend of $\mathrm{NO}_{2}$ columns during warm and cold months between 2005 and 2015 as well as monthly average values. From satellite observations, the $\mathrm{NO}_{2}$ columns over China increased with a slope of $0.063 \times 10^{15} \mathrm{molec} \mathrm{cm}^{-2} \mathrm{yr}^{-1}\left(4.07 \% \mathrm{yr}^{-1}\right)$ in warm 
months from 2005 to 2011 and then decreased with a slope of $-0.072 \mathrm{molec}^{-2}$ in warm months $\left(-3.62 \% \mathrm{yr}^{-1}\right)$ from 2011 to 2015 (Fig. 3). The decreasing trends were consistent with $\mathrm{NO}_{x}$ emissions since 2011 over China (decreasing from $24.04 \times 10^{6} \mathrm{t}$ in 2011 to $20.78 \times 10^{6} \mathrm{t}$ in 2014 , China Statistical Yearbook, http://www.stats.gov.cn/). During the 11th Chinese Five Year Plan (FYP) period (2006-2010), the Chinese government undertook a series of strategies to increase energy efficiency and to reduce $\mathrm{NO}_{x}$ emissions, but $\mathrm{NO}_{x}$ emissions were not successfully restrained, which created a big challenge for improving air quality over the country (Xia et al., 2016). During the 12th FYP period (2011-2015), more stringent strategies were implemented to control $\mathrm{NO}_{x}$ emissions, including the application of selective catalytic/noncatalytic reduction (SCR/SNCR) systems in the power sector; staged implementation of tighter vehicle emission standards; and a series of standards with aggressive emission limits for power, cement, and the iron and steel industries. These strategies are believed to have helped achieve national targets of $\mathrm{NO}_{x}$ emission abatement (Xia et al., 2016).

However, the satellite-retrieved $\mathrm{NH}_{3}$ columns increased with a slope of $0.118 \times 10^{15} \mathrm{molec} \mathrm{cm}^{-2} \mathrm{yr}^{-1}\left(2.37 \% \mathrm{yr}^{-1}\right)$ in warm months from 2008 to 2014 (Fig. 3). The percent increase rate for $\mathrm{NH}_{3}$ by year $\left(2.37 \% \mathrm{yr}^{-1}\right)$ from 2008 to 2014 is lower than that for $\mathrm{NO}_{2}\left(4.07 \% \mathrm{yr}^{-1}\right)$ from 2005 to 2011, although the absolute $\mathrm{NH}_{3}$ increase rate of $0.118 \times 10^{15} \mathrm{molec} \mathrm{cm}^{-2} \mathrm{yr}^{-1}$ from 2008 to 2014 was higher than absolute $\mathrm{NO}_{2}$ increase rate of $0.063 \times 10^{15}$ molec cm $^{-2} \mathrm{yr}^{-1}$ from 2005 to 2011. An increase in $\mathrm{NH}_{3}$ columns from IASI may be due to decreased $\mathrm{NH}_{3}$ removal, leading to a larger fraction maintained in the gaseous state for a long time rather than changing to the condensed phase. Specifically, $\mathrm{NH}_{3}$ is considered an important alkaline gas that is abundant in the atmosphere and is able to neutralize acidic components such as $\mathrm{HNO}_{3}$ and $\mathrm{H}_{2} \mathrm{SO}_{4}$ through the oxidation of $\mathrm{NO}_{x}$ and $\mathrm{SO}_{2}$, respectively ( $\mathrm{Li}$ et al., 2014; Liu et al., 2011; X. Liu et al., 2017; Xu et al., 2015). The decreased $\mathrm{NH}_{3}$ removal to some degree can be attributed to continuous decreased acidic gases, including $\mathrm{NO}_{2}$ and $\mathrm{SO}_{2}$, over China under a strong control policy in 12th FYP, which can largely decrease the fraction of the chemical conversion to $\left(\mathrm{NH}_{4}\right)_{2} \mathrm{SO}_{4}$ and $\mathrm{NH}_{4} \mathrm{NO}_{3}$ in the atmosphere. A increasing trend in $\mathrm{NH}_{3}$ columns may be associated with continuous $\mathrm{N}$ fertilizer use for guaranteeing an increase in crop production (Erisman et al., 2008). Although there was no strong $\mathrm{NH}_{3}$ emission control regulation, $\mathrm{N}$ fertilizer efficiency should be further improved over China. In 2015, the Ministry of Agriculture formally announced its "Zero Increase Action Plan" for national fertilizer use by 2020, which requires that the annual increase in total fertilizer use be less than $1 \%$ from 2015 to 2019 , with no further increase from 2020 (Liu et al., 2015).

If the Zero Increase Action Plan for $\mathrm{N}$ fertilizer can be effective, future $\mathrm{NH}_{3}$ emissions should be consistent with the current $\mathrm{NH}_{3}$ emissions. In addition, due to strong emission control of $\mathrm{NO}_{x}$, the $\mathrm{NO}_{x}$ emissions were believed to decrease significantly from 2011 to 2015 . We can reasonably make two major conclusions. First, the atmospheric $\mathrm{NO}_{2}$, as a key indicator of oxidized $\mathrm{N}$ compounds $\left(\mathrm{NO}_{2}, \mathrm{HNO}_{3}\right.$ and $\left.\mathrm{NO}_{3}^{-}\right)$, decreased since 2011, and will continue to decrease under the current policy. Second, the atmospheric $\mathrm{NH}_{3}$, as a key indicator of reduced $\mathrm{N}\left(\mathrm{NH}_{3}\right.$ and particulate $\left.\mathrm{NH}_{4}^{+}\right)$, will slightly increase or stay at the current level in the future with the Zero Increase Action Plan. Thus, due to a decreasing trend of oxidized $\mathrm{N}\left(\mathrm{NO}_{x}-\mathrm{N}\right)$, ammonia $\mathrm{N}\left(\mathrm{NH}_{x}-\mathrm{N}\right)$ should still dominate $\mathrm{N}_{\mathrm{r}}$ deposition (oxidized $\mathrm{N}$ plus reduced $\mathrm{N}$ ) in China, and is expected to play a more significant role in $\mathrm{N}_{\mathrm{r}}$ deposition. Therefore, monitoring the reduced $\mathrm{N}$ on a regional scale is encouraged to assist in enacting effective measures to protect the environments and public health, with respect to air, soil and water quality.

\subsubsection{Spatial pattern}

High $\mathrm{NH}_{3}$ columns were found in Beijing, Hebei, Henan, Shandong, Hubei and Jiangsu provinces and in eastern Sichuan Province (Fig. 4a), which were consistent with their high $\mathrm{NH}_{3}$ emissions due to intensive fertilizer application and livestock (Huang et al., 2012). Guangdong, Guangxi, Hunan and Jiangxi provinces also showed high $\mathrm{NH}_{3}$ columns, due to high volatilization from paddy fields in these regions, with rice being the dominant crop and contributing the most emissions. High $\mathrm{NH}_{3}$ columns in southern China are in agreement with the high percentage of paddy farmland area (Fig. S1a in the Supplement), and the high $\mathrm{NH}_{3}$ columns in northern China are in agreement with the high percentage of dry farmland area (Fig. S1b). In addition, the $\mathrm{NH}_{3}$ emissions from vehicles in urban areas could also contribute to the observed high $\mathrm{NH}_{3}$ columns. For example, in Beijing, the contribution of vehicles equipped with catalytic converters, particularly since the introduction of three-way catalysts, to non-agricultural $\mathrm{NH}_{3}$ emissions has recently been considered and might be the most important factor influencing $\mathrm{NH}_{3}$ concentrations in urban cities (Meng et al., 2011; Xu et al., 2017). In addition, Xinjiang Province also emits remarkable $\mathrm{NH}_{3}$ emissions related to sheep manure management (Huang et al., 2012; Kang et al., 2016; Zhou et al., 2015; Liu et al., 2017a). The lower $\mathrm{NH}_{3}$ columns are located mostly in the Tibetan Plateau area, where there is a minimal amount of arable land and low use of synthetic nitrogenous fertilizers.

$\mathrm{NO}_{2}$ columns (Fig. 4b) show significantly higher values over vast areas covering North China, East China, and the Sichuan Basin. The $\mathrm{NO}_{2}$ columns also show high values over the Pearl River Delta, the southern part of Northeast China, and some areas in Northwest China. High $\mathrm{NO}_{2}$ columns are mostly distributed in populated areas (Fig. S2), where there is a mix of various anthropogenic $\mathrm{NO}_{x}$ sources, such as vehicles and industrial complexes (Wang et al., 2012; Xu et al., 2015; Meng et al., 2010). It should be noted that an enhanced 
(a) $\mathrm{OMI} \mathrm{NO}$ at 13:45

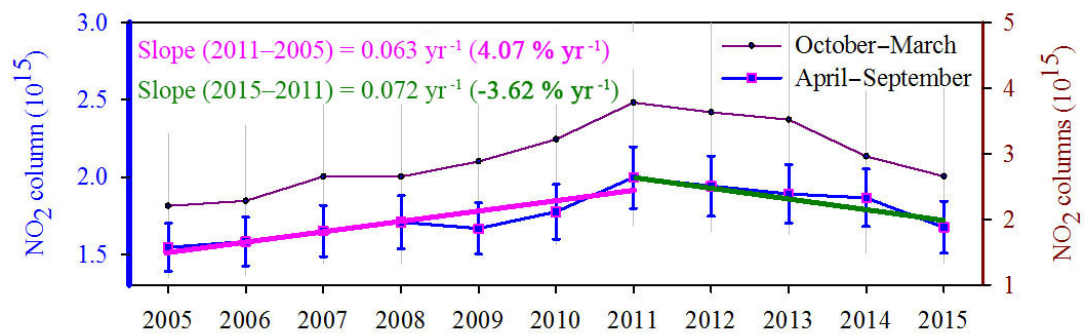

(b) IASI $\mathrm{NH}_{3}$ at 09:30

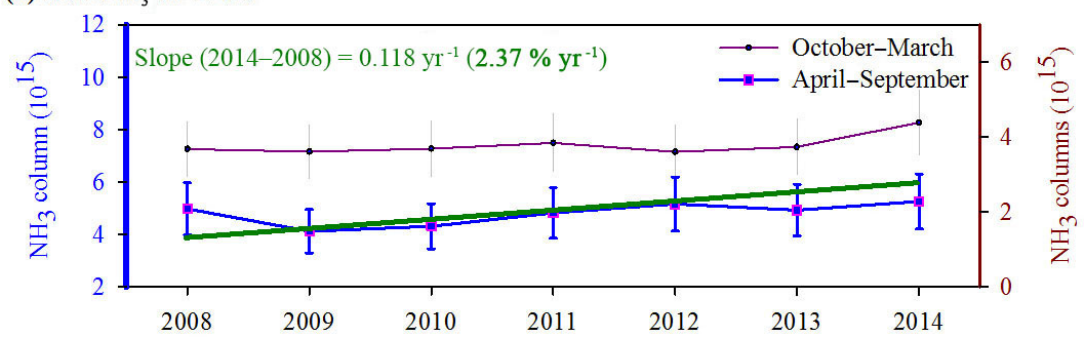

Figure 3. Time series of average $\mathrm{OMI} \mathrm{NO}$ and $\mathrm{IASI} \mathrm{NH}_{3}$ columns over China during warm months (April-September) and cold months (October-March). The time period of $\mathrm{NO}_{2}$ columns was from 2005 to 2015, while the time span of $\mathrm{NH}_{3}$ columns was from 2008 to 2014 over China. The associated mean error for each period is presented here as error bars. The percent increase or decrease rate (\%) was the long-term mean, calculated as $100 \times\left(\frac{Y_{2}-Y_{1}}{Y_{1}}+\frac{Y_{3}-Y_{2}}{Y_{2}}+\ldots+\frac{Y_{n+1}-Y_{n}}{Y_{n}}\right) \times \frac{1}{n}$.
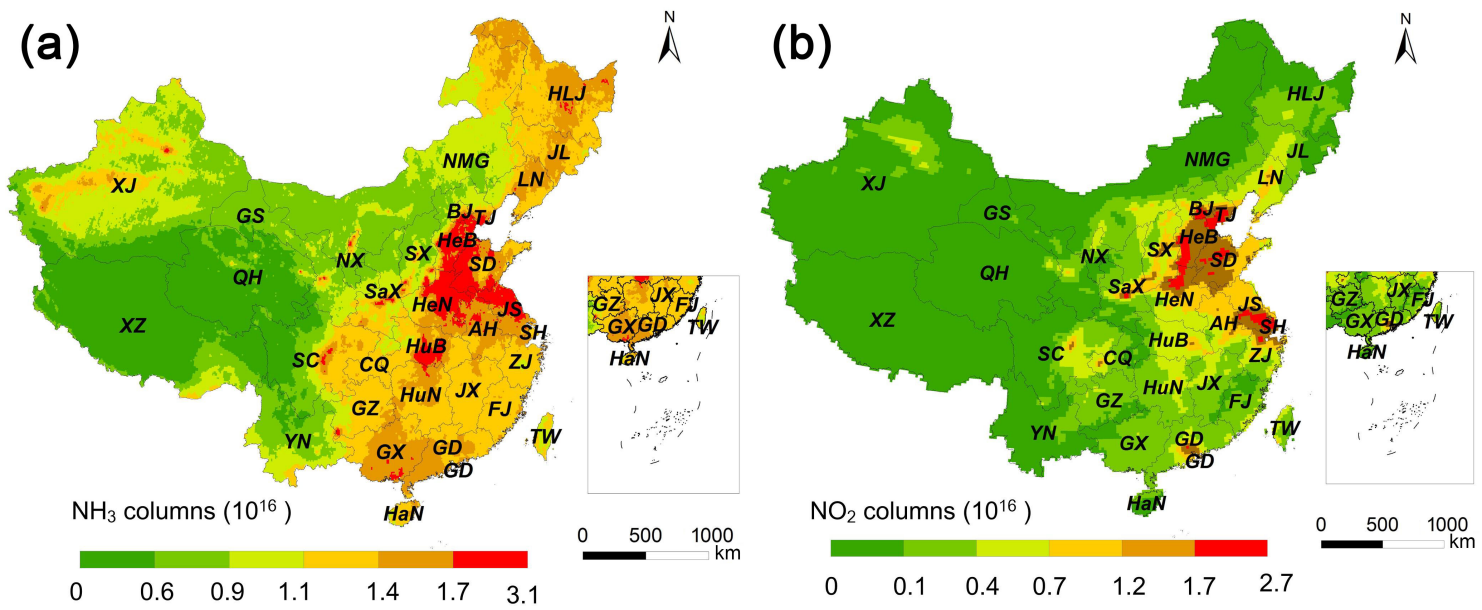

Figure 4. Spatial distribution of the annual $\mathrm{NH}_{3}$ (a) and $\mathrm{NO}_{2}$ (b) columns (molecules $\mathrm{cm}^{-2} \mathrm{yr}^{-1}$ ). The full provincial names are Beijing (BJ), Tianjin (TJ), Hebei (HeB), Shandong (SD), Shanxi (SX), Henan (HeN), Shaanxi (SaX), Liaoning (LN), Jilin (JL), Heilongjiang (HLJ), Neimenggu (NMG), Gansu (GS), Ningxia (NX), Xinjiang (XJ), Shanghai (SH), Jiangsu (JS), Zhejiang (ZJ), Anhui (AH), Hubei (HuB), Hunan (HuN), Jiangxi (JX), Fujian (FJ), Guangdong (GD), Hainan (HaN), Yunnan (YN), Guizhou (GZ), Chongqing (CQ), Sichuan (SC), Guangxi (GX), Xizang (XZ) and Qinghai (QH).

emission intensity from transportation is confirmed since 2005 , even with staged implementation of tightened emission standards for on-road vehicles (Wang et al., 2012). For example, $\mathrm{NO}_{x}$ emissions from transportation grew to $30 \%$ for the whole country in 2014, and the values reached 44, 55, and $33 \%$ for Beijing, Shanghai, and Guangdong, respectively (Xia et al., 2016). Therefore, transportation is believed to play an increasingly important role in regional $\mathrm{NO}_{2}$ pollution, especially when emissions from stationary sources are gradually controlled through increased penetration of selective catalytic/non-catalytic reduction (SCR/SNCR) systems.

\subsubsection{Limitations of satellite observations}

It is difficult to gain whole coverage over China based on the daily data for both IASI $\mathrm{NH}_{3}$ and $\mathrm{OMI} \mathrm{NO}$. For daily $\mathrm{NO}_{2}$, the spatial coverage gained by OMI was influenced by cloud radiance fractions, surface albedo, solar zenith angles, 
row anomaly and so on (Russell et al., 2011; De Smedt et al., 2015). The "row anomaly" issue resulting from the OMI instrumental problem had an impact on approximately half of the rows undergoing unpredictable patterns in cross-track directions relying on latitudes and seasons and prevented obtaining convincing daily product with continuous coverage (Boersma et al., 2011, 2016). For $\mathrm{NH}_{3}$, the satellite instruments were strongly dependent on the meteorological conditions such as cloud fractions or the availability of the temperature profiles (Van Damme et al., 2014a; Boersma et al., 2011), and we cannot retrieve the whole coverage based on daily data over China. It will be beneficial to analyze a very local region with enough numbers of observations, but not appropriate to analyze such large coverage over China.

Facing this big challenge, we used the monthly data for the trend analysis over China. The uncertainty in DOMINO v2.0 $\mathrm{NO}_{2}$ columns has been well documented in Boersma et al. (2011), and the relative error is reported lower than 20-30\% in East Asia by an improved altitude-dependent air mass factor look-up table, a more realistic atmospheric profile, an increased number of reference vertical layers and advanced surface albedos (Boersma et al., 2011). The reader is strongly suggested to refer to Boersma et al. (2011) for more details on the uncertainty analysis.

The potential uncertainty of IASI $\mathrm{NH}_{3}$ columns resulted from IASI observation instruments and retrieval algorithms. In this paper, the $\mathrm{NH}_{3}$ datasets were generated based on the recent-updated robust and flexible $\mathrm{NH}_{3}$ retrieval algorithms, which were designed to overcome some shortcomings of the current algorithms (Whitburn et al., 2016a). The current algorithms were designed firstly to calculate the hyperspectral range index (HRI), a measure for the $\mathrm{NH}_{3}$ signature strength in the spectrum, and then converted to IASI $\mathrm{NH}_{3}$ columns by using the thermal contrast (TC) and lookup tables (LUTs) of the (HRI, TC) pair corresponding to $\mathrm{NH}_{3}$ columns. The retrieval of HRIs is strongly dependent on the amount of $\mathrm{NH}_{3}$ and the thermal state of the atmosphere (Whitburn et al., 2016a). The quality of the IASI $\mathrm{NH}_{3}$ product has been validated by atmospheric chemistry transport models (CTMs), ground-based and airborne measurements, and $\mathrm{NH}_{3}$ total columns obtained with ground-based Fourier transform infrared spectroscopy (FTIR). A first validation of the IASI $\mathrm{NH}_{3}$ using the LOTOS-EUROS model was conducted over Europe, indicating the respective consistency of IASI measurements and model simulations (Van Damme et al., 2014b). A first evaluation of IASI $\mathrm{NH}_{3}$ dataset using ground-based measurements was then made worldwide, presenting consistency with the available ground-based observations and denoting promising results for evaluation by using independent airborne data (Van Damme et al., 2015). A first validation of IASI $\mathrm{NH}_{3}$ dataset using ground-based FTIR derived $\mathrm{NH}_{3}$ total columns was evaluated, demonstrating a mean relative difference of $-32.4 \pm(56.3) \%$, a correlation $r$ of 0.8 with a slope of 0.73 (Dammers et al., 2016).

\subsection{Atmospheric chemistry transport model $\mathrm{NO}_{2}$ and $\mathrm{NH}_{3}$ columns since 2008}

Satellite $\mathrm{NO}_{2}$ and $\mathrm{NH}_{3}$ columns were observed at overpass time as an instantaneous point in a day (at 09:30 for IASI $\mathrm{NH}_{3}$ and at 13:45 for OMI $\mathrm{NO}_{2}$ local time). These instantaneous satellite observations may not be representative of the temporal trend analysis over China. We further retrieved the monthly variations in $\mathrm{NO}_{2}$ and $\mathrm{NH}_{3}$ columns since 2008 from MOZART varying $6 \mathrm{~h}$ every day (00:00, 06:00, 12:00, 18:00). We compared the temporal trend analysis of $\mathrm{NO}_{2}$ from MOZART at 12:00 with that gained from satellite at the overpass time (OMI 13:45 local time) as well as for $\mathrm{NH}_{3}$.

Figure 5 shows the $\mathrm{NO}_{2}$ columns at 12:00 during warm and cold months between 2008 and 2015 from MOZART. The percent increase rate for $\mathrm{NO}_{2}$ columns at 12:00 during warm months (April-September) between 2008 and 2011 was $4.02 \% \mathrm{yr}^{-1}$ (Fig. 5), which was comparable with that $\left(4.23 \% \mathrm{yr}^{-1}\right)$ derived from OMI (Fig. 3). During 2011-2015, we found a slightly lower decrease rate $\left(-2.93 \% \mathrm{yr}^{-1}\right)$ in $\mathrm{NO}_{2}$ columns during warm months at 12:00 from MOZART (Fig. 5) than that $\left(-3.62 \% \mathrm{yr}^{-1}\right)$ gained from OMI at 13:45 (Fig. 3). The temporal variations in $\mathrm{NO}_{2}$ columns at 12:00 from MOZART were generally in accord with those from OMI at 13:45 local time. Figure 5 also demonstrates the average $\mathrm{NO}_{2}$ columns (averaged at 00:00, 06:00, 12:00 and 18:00) during warm and cold months between 2008 and 2015. We found an increase rate at 12:00 $(4.02 \%)$ close to that averaged at 00:00, 06:00, 12:00 and 18:00 $(4.23 \%)$ before 2011, as well as a similar decrease rate at $12: 00(-2.93 \%)$ and average $(-3.07 \%)$, implying that the temporal trend analysis at 12:00 vs. that averaged at 00:00, 06:00, 12:00 and 18:00 can be considered mostly consistent over China from MOZART.

For $\mathrm{NH}_{3}$, we found the percent increase rate at 12:00 during warm months between 2008 and 2015 was $1.30 \% \mathrm{yr}^{-1}$ from MOZART (Fig. 5), which was lower than that $\left(2.37 \% \mathrm{yr}^{-1}\right)$ from IASI during 2008-2014. The percent increase rate by daily average (at 00:00, 06:00, 12:00 and 18:00) during warm months between 2008 and 2015 was $1.36 \% \mathrm{yr}^{-1}$ from MOZART (Fig. 5). In MOZART-4, the alkaline gaseous $\mathrm{NH}_{3}$ and the acidic gaseous $\mathrm{NO}_{2}$ (the precursor for $\mathrm{HNO}_{3}$ ) and $\mathrm{SO}_{2}$ are very important precursors for bulk $\mathrm{NH}_{4} \mathrm{NO}_{3}$ and $\left(\mathrm{NH}_{4}\right)_{2} \mathrm{SO}_{4}$ particles, which form the primary system of gas-particle partitioning $\left(\mathrm{NH}_{3}-\mathrm{NH}_{4}^{+}-\mathrm{NO}_{x}-\right.$ $\mathrm{NO}_{3}^{-}-\mathrm{SO}_{2}-\mathrm{SO}_{4}^{2-}$ ). The chemical shifts between particulate $\mathrm{NH}_{4} \mathrm{NO}_{3}$ and gaseous $\mathrm{NH}_{3}$ and $\mathrm{NO}_{x}$ are correlated with the abundance of $\mathrm{NH}_{3}$ and $\mathrm{NO}_{x}$ and meteorological factors. The decreased abundance of $\mathrm{NO}_{x}$ between 2011 and 2015 may also contribute to an increase in the $\mathrm{NH}_{3}$ abundance in the gas stage resulting from decreased conversion to particulate $\mathrm{NH}_{4} \mathrm{NO}_{3}$. 
(a) MOZART $\mathrm{NO}_{2}$

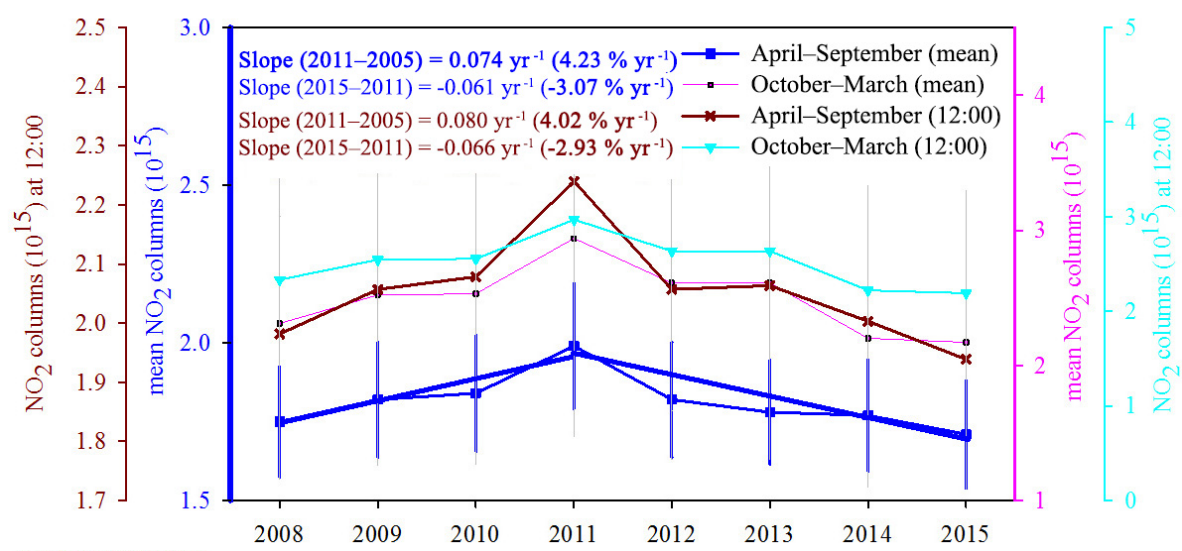

(b) MOZART $\mathrm{NH}_{3}$

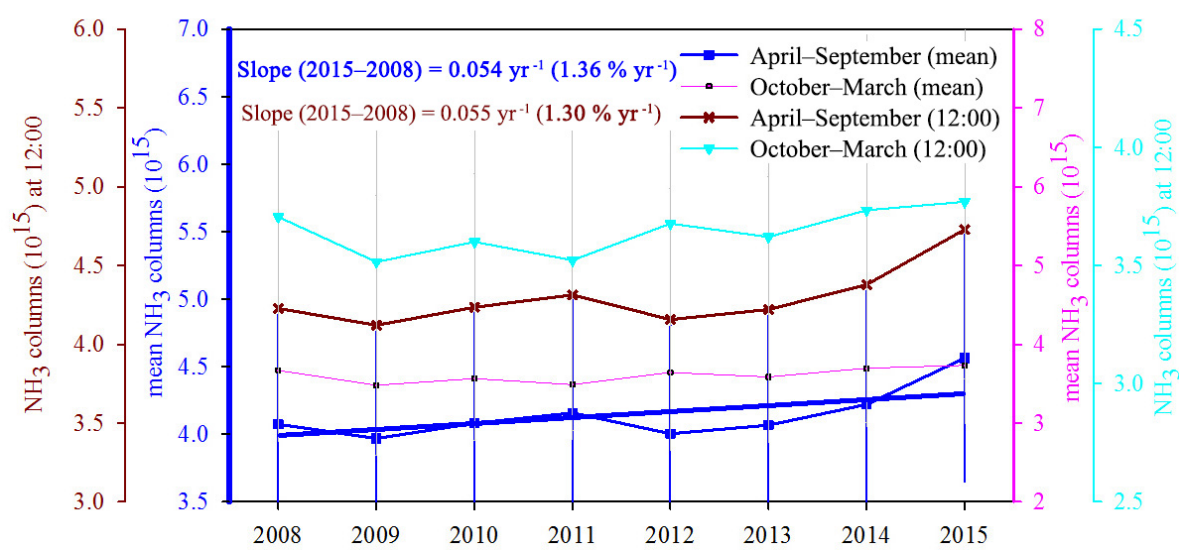

Figure 5. Time series of MOZART $\mathrm{NO}_{2}$ and $\mathrm{NH}_{3}$ columns over China during average warm months (April-September) and cold months (October-March) from 2008 to 2015. The mean columns were calculated by averaging the columns at 00:00, 06:00, 12:00 and 18:00. The associated mean error for each period is presented here as error bars.

\subsection{Implications for estimating long-term $\mathrm{N}_{\mathrm{r}}$ deposition datasets and recommendations for future work}

We found both the $\mathrm{NO}_{x}$ and $\mathrm{NH}_{3}$ over China increased continuously from 1980 to 2010 based on emissions data from REAS and EDGAR. In recent years, based on satellite observations, we found an increase of $2.37 \% \mathrm{yr}^{-1}$ in $\mathrm{NH}_{3}$ columns during 2008-2014. We also found high-level $\mathrm{NO}_{2}$ columns over China from 2005-2011 $\left(4.07 \% \mathrm{yr}^{-1}\right)$ but a decrease from 2011 to $2015\left(-3.62 \% \mathrm{yr}^{-1}\right)$. Despite the decline, the $\mathrm{NO}_{2}$ columns during 2011-2015 were still at a high level, with an average of $1.87 \times 10^{15} \mathrm{molec} \mathrm{cm}^{-2} \mathrm{yr}^{-1}$, compared with that $\left(1.65 \times 10^{15}\right.$ molec $\left.\mathrm{cm}^{-2} \mathrm{yr}^{-1}\right)$ during 2005 2010. Notably, these emissions certainly lead to the deposition of atmospheric $\mathrm{N}_{\mathrm{r}}$ in the form of dry and wet processes into aquatic ecosystems and terrestrial, with implications of effects on ecosystem and human health, biological diversity and greenhouse gas balances (Lu et al., 2016). Hence, it is very crucial to estimate $\mathrm{N}_{\mathrm{r}}$ deposition with high spatiotemporal resolutions in order to drive ecological models such as the DeNitrification-DeComposition (DNDC) model and Integrated BIosphere Simulator (IBIS) to assess its impact on soil, forest, water and greenhouse balance. Here, we call for a long-term dataset of $\mathrm{N}_{\mathrm{r}}$ depositions both regionally and globally to investigate how the $\mathrm{N}$ emissions affect the environment. A challenge still exits in estimating both the dry $\left(\mathrm{NO}_{2}, \mathrm{HNO}_{3}\right.$ particulate $\mathrm{NO}_{3}^{-}, \mathrm{NH}_{3}$ and particulate $\left.\mathrm{NH}_{4}^{+}\right)$ and wet $\left(\mathrm{NH}_{4}^{+}\right.$and $\mathrm{NO}_{3}^{-}$in precipitation) depositions for a long-term dataset such as since 1980 or earlier, possibly due to the complex scheme of $\mathrm{N}$ transformations and transportation or limited available data from emissions, satellites and a limited number of ground measurements.

Satellite observations provide a new perspective for estimating $\mathrm{N}_{\mathrm{r}}$ depositions regionally and have been used to improve the estimation performance. For example, to improve the modeling performance in dry gaseous $\mathrm{NO}_{2}$ depositions from GEOS-Chem (Goddard Earth Observing System chemical transport model), Nowlan et al. (2014) applied the OMI $\mathrm{NO}_{2}$ columns to calibrate the simulated ground $\mathrm{NO}_{2}$ concentrations, and then estimated the deposition between 2005 
and 2007. Our previous work focusing on the dry particulate $\mathrm{NO}_{3}^{-}$deposition over China was also based on the OMI $\mathrm{NO}_{2}$ columns, MOZART simulations and monitored-based sources (Liu et al., 2017b). Geddes et al. (2017) used the satellite $\mathrm{NO}_{2}$ columns from GOME, GOME-2 and SCIAMACHY instruments to calibrate the $\mathrm{NO}_{x}$ emissions in GEOS-Chem to estimate the $\mathrm{NO}_{x}$ depositions since 1996. The simulations combining the satellite measurements and CTMs to derive $\mathrm{N}_{\mathrm{r}}$ depositions (Geddes and Martin, 2017; Nowlan et al., 2014) in recent years will provide relatively accurate datasets (certainly need to be validated and modified by ground measurements).

Despite progress in satellite techniques in recent decades (for $\mathrm{NO}_{2}$ since 1997 by GOME and for $\mathrm{NH}_{3}$ since 2008 by IASI), we can find very few studies concerning $\mathrm{N}_{\mathrm{r}}$ depositions before 1997 based on satellite observations. Thus, with the help of emissions data such as REAS and EDGAR, we can derive long-term $\mathrm{N}_{\mathrm{r}}$ depositions, especially before 1997 . Long-term emissions data such as REAS and EDGAR will provide a valuable dataset to expand the modeling of $\mathrm{N}_{\mathrm{r}}$ depositions in recent years. In order to derive the $\mathrm{N}_{\mathrm{r}}$ depositions from the emission data, CTMs are frequently used through modeling the wet (simplified as the product of scavenging efficiency and precipitation amount) and dry processes (simplified as the inferential method by multiplying the deposition velocity and gaseous or particulate concentrations). However, we still lack a comprehensive dataset of gridded longterm $\mathrm{N}_{\mathrm{r}}$ depositions including both the dry $\left(\mathrm{NO}_{2}, \mathrm{HNO}_{3}\right.$ particulate $\mathrm{NO}_{3}^{-}, \mathrm{NH}_{3}$ and particulate $\left.\mathrm{NH}_{4}^{+}\right)$and wet $\left(\mathrm{NH}_{4}^{+}\right.$and $\mathrm{NO}_{3}^{-}$in precipitation) processes over China, which will be addressed in future work.

Another gap is that, all the abovementioned studies focused on the $\mathrm{NO}_{x}$ depositions and did not derive the $\mathrm{NH}_{y}$ $\left(\mathrm{NH}_{3}\right.$ and $\left.\mathrm{NH}_{4}^{+}\right)$depositions over China. Our recent work (Liu et al., 2017a) using IASI $\mathrm{NH}_{3}$ columns combining the vertical profiles from MOZART benefits our understanding of the ground $\mathrm{NH}_{3}$ concentrations over China, and the satellite-derived ground $\mathrm{NH}_{3}$ concentrations were generally in accord with the national measurements from NNDMN. To date, there are still no reports of using the satellite $\mathrm{NH}_{3}$ columns to derive the temporal and regional $\mathrm{NH}_{y}$ depositions over China, which dominated the total $\mathrm{N}_{\mathrm{r}}$ depositions $\left(\mathrm{NO}_{x}\right.$ plus $\mathrm{NH}_{y}$; L. Liu et al., 2016; Liu et al., 2013). The gaps in modeling of $\mathrm{NH}_{y}$ depositions by applying the satellite observations combining the CTM simulations require more efforts and further research.

\section{Conclusions}

Atmospheric ammonia $\left(\mathrm{NH}_{3}\right)$ and nitrogen dioxide $\left(\mathrm{NO}_{2}\right)$ play an important role in determining air quality, environmental degradation and climate change. The emission data, satellite observations and atmospheric transport modeling have great potential for understanding the temporal varia- tions in atmospheric $\mathrm{NH}_{3}$ and $\mathrm{NO}_{2}$ on a regional scale, with high spatial and temporal resolutions. This study analyzed the characteristics of atmospheric $\mathrm{NH}_{3}$ and $\mathrm{NO}_{2}$ over China since 1980 based on the multiple datasets. The major findings were as follows:

1. Based on emission data, a significant continuous increasing trend in both $\mathrm{NH}_{3}$ and $\mathrm{NO}_{x}$ were observed from REAS (for $\mathrm{NH}_{3} 0.17$ and for $\mathrm{NO}_{x}$ $0.16 \mathrm{~kg} \mathrm{Nha}^{-1} \mathrm{yr}^{-2}$ ) and EDGAR (for $\mathrm{NH}_{3} 0.24$ and for $\mathrm{NO}_{x} 0.17 \mathrm{~kg} \mathrm{~N} \mathrm{ha}^{-1} \mathrm{yr}^{-2}$ ) over China during 19802010.

2. Based on the satellite observations, we found highlevel $\mathrm{NH}_{3}$ columns with the percent increase rate of $2.37 \% \mathrm{yr}^{-1}$ from 2008 to 2014 . For $\mathrm{NO}_{2}$, we found continuous high-level $\mathrm{NO}_{2}$ columns over China from 2005-2011 but a decrease from 2011 to 2015 (still at a high level). The decrease of $\mathrm{NO}_{2}$ columns may result from more stringent strategies taken to control $\mathrm{NO}_{x}$ emissions during the 12th Five Year Plan, including successful application of SCR/SNCR systems in the power sector, tighter emission standards on vehicles and a series of standards with aggressive emission limits. An increasing trend in $\mathrm{NH}_{3}$ columns may be due to continuous $\mathrm{N}$ fertilizer use for guaranteeing a continuous increase in crop production. An increase in $\mathrm{NH}_{3}$ columns may be due to decreased $\mathrm{NH}_{3}$ removal leading to a larger fraction being maintained in the gaseous state for a long time rather than changing to the condensed phase, which may be related to continuously decreasing acidic gases, including $\mathrm{NO}_{2}$ and $\mathrm{SO}_{2}$, over China under a strong control policy in 12th FYP.

3. Based on MOZART simulations, the temporal variations in $\mathrm{NO}_{2}$ columns at 12:00 from MOZART were generally in accord with those from OMI at 13:45 local time. We also found a close increase rate at 12:00 $(4.02 \%)$ with that averaged at 00:00, 06:00, 12:00 and 18:00 (4.23\%) before 2011 , as well as a similar decrease rate at 12:00 $(-2.93 \%)$ and the average $(-3.07 \%)$. For $\mathrm{NH}_{3}$, we found a lower percent increase rate from MOZART $\left(1.30 \% \mathrm{yr}^{-1}\right)$ than IASI $\left(2.37 \% \mathrm{yr}^{-1}\right)$ between 2008 and 2014.

4. The multiple datasets used in the current work have implications for estimating long-term $\mathrm{N}_{\mathrm{r}}$ deposition datasets. The simulations combining the satellite measurements and CTMs to derive $\mathrm{N}_{\mathrm{r}}$ depositions will provide relatively accurate datasets, and the REAS and EDGAR emissions have potential to expand the modeling $\mathrm{N}_{\mathrm{r}}$ depositions to long-term datasets. In particular, modeling of $\mathrm{NH}_{y}$ depositions by applying satellite observations combining the CTM simulations requires more efforts and further research. 
Data availability. All data sets related to this paper can be obtained by contacting the principal investigator, Xiuying Zhang (lzhxy77@163.com).

\section{The Supplement related to this article is available online at https://doi.org/10.5194/acp-17-9365-2017-supplement.}

Competing interests. The authors declare that they have no conflict of interest.

Acknowledgements. We acknowledge the free use of tropospheric $\mathrm{NO}_{2}$ column data from the OMI sensor from www.temis.nl. The $\mathrm{NH}_{3}$ data were obtained by the Atmospheric Spectroscopy Group at Université Libre de Bruxelles (ULB; http://www.ulb.ac.be/cpm/atmosphere.html). Simon Whitburn and Martin Van Damme are acknowledged for making the data available and for their help in how to use them. We also thank Louisa Emmons from National Center for Atmospheric Research (NCAR) for providing the MOZART output data for the trend analysis. This study is supported by the National Natural Science Foundation of China (no. 41471343, 40425007 and 41101315).

Edited by: Jennifer G. Murphy

Reviewed by: two anonymous referees

\section{References}

Basto, S., Thompson, K., Phoenix, G., Sloan, V., Leake, J., and Rees, M.: Long-term nitrogen deposition depletes grassland seed banks, Nat. Commun., 6, 1-6, https://doi.org/10.1038/ncomms7185, 2015.

Beer, R., Shephard, M. W., Kulawik, S. S., Clough, S. A., Eldering, A., Bowman, K. W., Sander, S. P., Fisher, B. M., Payne, V. H., Luo, M., Osterman, G. B., and Worden, J. R.: First satellite observations of lower tropospheric ammonia and methanol, Geophys. Res. Lett., 35, L09801, https://doi.org/10.1029/2008GL033642, 2008.

Beig, G. and Singh, V.: Trends in tropical tropospheric column ozone from satellite data and MOZART model, Geophys. Res. Lett., 34, L17801, https://doi.org/10.1029/2007GL030460, 2007.

Boersma, K. F., Eskes, H. J., Veefkind, J. P., Brinksma, E. J., van der A, R. J., Sneep, M., van den Oord, G. H. J., Levelt, P. F., Stammes, P., Gleason, J. F., and Bucsela, E. J.: Near-real time retrieval of tropospheric $\mathrm{NO}_{2}$ from OMI, Atmos. Chem. Phys., 7, 2103-2118, https://doi.org/10.5194/acp-7-2103-2007, 2007.

Boersma, K. F., Eskes, H. J., Dirksen, R. J., van der A, R. J., Veefkind, J. P., Stammes, P., Huijnen, V., Kleipool, Q. L., Sneep, M., Claas, J., Leitão, J., Richter, A., Zhou, Y., and Brunner, D.: An improved tropospheric $\mathrm{NO}_{2}$ column retrieval algorithm for the Ozone Monitoring Instrument, Atmos. Meas. Tech., 4, 19051928, https://doi.org/10.5194/amt-4-1905-2011, 2011.

Boersma, K. F., Vinken, G. C. M., and Eskes, H. J.: Representativeness errors in comparing chemistry transport and chemistry climate models with satellite UV-Vis tropospheric column retrievals, Geosci. Model Dev., 9, 875-898, https://doi.org/10.5194/gmd-9-875-2016, 2016.

Brasseur, G., Hauglustaine, D., Walters, S., Rasch, P., Müller, J. F., Granier, C., and Tie, X.: MOZART, a global chemical transport model for ozone and related chemical tracers: 1. Model description, J. Geophys. Res.-Atmos., 103, 28265-28289, 1998.

Canfield, D. E., Glazer, A. N., and Falkowski, P. G.: The Evolution and Future of Earth's Nitrogen Cycle, Science, 330, 192-196, https://doi.org/10.1126/science.1186120, 2010

Castellanos, P., Boersma, K. F., Torres, O., and de Haan, J. F.: OMI tropospheric $\mathrm{NO}_{2}$ air mass factors over South America: effects of biomass burning aerosols, Atmos. Meas. Tech., 8, 3831-3849, https://doi.org/10.5194/amt-8-3831-2015, 2015.

Clarisse, L., Clerbaux, C., Dentener, F., Hurtmans, D., and Coheur, P.-F.: Global ammonia distribution derived from infrared satellite observations, Nat. Geosci., 2, 479-483, 2009.

Cofala, J., Amann, M., Klimont, Z., Kupiainen, K., and HöglundIsaksson, L.: Scenarios of global anthropogenic emissions of air pollutants and methane until 2030, Atmos. Environ., 41, 84868499, https://doi.org/10.1016/j.atmosenv.2007.07.010, 2007.

Coheur, P.-F., Clarisse, L., Turquety, S., Hurtmans, D., and Clerbaux, C.: IASI measurements of reactive trace species in biomass burning plumes, Atmos. Chem. Phys., 9, 5655-5667, https://doi.org/10.5194/acp-9-5655-2009, 2009.

Crippa, M., Janssens-Maenhout, G., Dentener, F., Guizzardi, D., Sindelarova, K., Muntean, M., Van Dingenen, R., and Granier, C.: Forty years of improvements in European air quality: regional policy-industry interactions with global impacts, Atmos. Chem. Phys., 16, 3825-3841, https://doi.org/10.5194/acp-163825-2016, 2016.

Dammers, E., Palm, M., Van Damme, M., Vigouroux, C., Smale, D., Conway, S., Toon, G. C., Jones, N., Nussbaumer, E., Warneke, T., Petri, C., Clarisse, L., Clerbaux, C., Hermans, C., Lutsch, E., Strong, K., Hannigan, J. W., Nakajima, H., Morino, I., Herrera, B., Stremme, W., Grutter, M., Schaap, M., Wichink Kruit, R. J., Notholt, J., Coheur, P.-F., and Erisman, J. W.: An evaluation of IASI-NH 3 with ground-based Fourier transform infrared spectroscopy measurements, Atmos. Chem. Phys., 16, 10351-10368, https://doi.org/10.5194/acp-16-10351-2016, 2016.

De Smedt, I., Stavrakou, T., Hendrick, F., Danckaert, T., Vlemmix, T., Pinardi, G., Theys, N., Lerot, C., Gielen, C., Vigouroux, C., Hermans, C., Fayt, C., Veefkind, P., Müller, J.-F., and Van Roozendael, M.: Diurnal, seasonal and long-term variations of global formaldehyde columns inferred from combined OMI and GOME-2 observations, Atmos. Chem. Phys., 15, 12519-12545, https://doi.org/10.5194/acp-15-12519-2015, 2015.

Emmons, L. K., Walters, S., Hess, P. G., Lamarque, J.-F., Pfister, G. G., Fillmore, D., Granier, C., Guenther, A., Kinnison, D., Laepple, T., Orlando, J., Tie, X., Tyndall, G., Wiedinmyer, C., Baughcum, S. L., and Kloster, S.: Description and evaluation of the Model for Ozone and Related chemical Tracers, version 4 (MOZART-4), Geosci. Model Dev., 3, 43-67, https://doi.org/10.5194/gmd-3-43-2010, 2010.

Erisman, J. W., Sutton, M. A., Galloway, J., Klimont, Z., and Winiwarter, W.: How a century of ammonia synthesis changed the world, Nat. Geosci., 1, 636-639, 2008. 
Foy, B. D., Lu, Z., and Streets, D. G.: Satellite NO2 retrievals suggest China has exceeded its NOxreduction goals from the twelfth Five-Year Plan, Scientific Reports, 6, 35912, 2016.

Fu, B., Li, S., Yu, X., Yang, P., Yu, G., Feng, R., and Zhuang, X.: Chinese ecosystem research network: Progress and perspectives, Ecological Complexity, 7, 225-233, https://doi.org/10.1016/j.ecocom.2010.02.007, 2010.

Galloway, J. N., Dentener, F. J., Capone, D. G., Boyer, E. W., Howarth, R. W., Seitzinger, S. P., Asner, G. P., Cleveland, C. C., Green, P. A., Holland, E. A., Karl, D. M., Michaels, A. F., Porter, J. H., Townsend, A. R., and Vöosmarty, C. J.: Nitrogen Cycles: Past, Present, and Future, Biogeochemistry, 70, 153-226, https://doi.org/10.1007/s10533-004-0370-0, 2004.

Galloway, J. N., Townsend, A. R., Erisman, J. W., Bekunda, M., Cai, Z., Freney, J. R., Martinelli, L. A., Seitzinger, S. P., and Sutton, M. A.: Transformation of the Nitrogen Cycle: Recent Trends, Questions, and Potential Solutions, Science, 320, 889892, https://doi.org/10.1126/science.1136674, 2008.

Geddes, J. A. and Martin, R. V.: Global deposition of total reactive nitrogen oxides from 1996 to 2014 constrained with satellite observations of $\mathrm{NO}_{2}$ columns, Atmos. Chem. Phys. Discuss., https://doi.org/10.5194/acp-2016-1100, in review, 2017.

Huang, X., Song, Y., Li, M., Li, J., Huo, Q., Cai, X., Zhu, T., Hu, M., and Zhang, H.: A high resolution ammonia emission inventory in China, Global Biogeochem. Cy., 26, 1-14, 2012.

Ialongo, I., Herman, J., Krotkov, N., Lamsal, L., Boersma, K. F., Hovila, J., and Tamminen, J.: Comparison of OMI $\mathrm{NO}_{2}$ observations and their seasonal and weekly cycles with ground-based measurements in Helsinki, Atmos. Meas. Tech., 9, 5203-5212, https://doi.org/10.5194/amt-9-5203-2016, 2016.

Jgj, O., Jjm, B., Jahw, P., Bakker, J., Ajh, V., and Jpj, B.: Applications of EDGAR Emission Database for Global Atmospheric Research, Rijksinstituut Voor Volksgezondheid En Milieu Rivm, 2002.

Kang, Y., Liu, M., Song, Y., Huang, X., Yao, H., Cai, X., Zhang, H., Kang, L., Liu, X., Yan, X., He, H., Zhang, Q., Shao, M., and Zhu, T.: High-resolution ammonia emissions inventories in China from 1980 to 2012, Atmos. Chem. Phys., 16, 2043-2058, https://doi.org/10.5194/acp-16-2043-2016, 2016.

Klimont, Z., Cofala, J., Schöpp, W., Amann, M., Streets, D. G., Ichikawa, Y., and Fujita, S.: Projections of $\mathrm{SO}_{2}, \mathrm{NO}_{x}, \mathrm{NH}_{3}$ and VOC Emissions in East Asia Up to 2030, Water Air Soil Poll., 130, 193-198, 2001.

Kurokawa, J., Ohara, T., Morikawa, T., Hanayama, S., JanssensMaenhout, G., Fukui, T., Kawashima, K., and Akimoto, H.: Emissions of air pollutants and greenhouse gases over Asian regions during 2000-2008: Regional Emission inventory in ASia (REAS) version 2, Atmos. Chem. Phys., 13, 11019-11058, https://doi.org/10.5194/acp-13-11019-2013, 2013.

Lamsal, L. N., Duncan, B. N., Yoshida, Y., Krotkov, N. A., Pickering, K. E., Streets, D. G., and Lu, Z.: U.S. $\mathrm{NO}_{2}$ trends (2005-2013): EPA Air Quality System (AQS) data versus improved observations from the Ozone Monitoring Instrument (OMI), Atmos. Environ., 110, 130-143, https://doi.org/10.1016/j.atmosenv.2015.03.055, 2015.

Lan, Z., Jenerette, G. D., Zhan, S., Li, W., Zheng, S., and Bai, Y.: Testing the scaling effects and mechanisms of $\mathrm{N}$-induced biodiversity loss: evidence from a decade-long grassland ex- periment, J. Ecol., 103, 750-760, https://doi.org/10.1111/13652745.12395, 2015.

Li, Y., Schwandner, F. M., Sewell, H. J., Zivkovich, A., Tigges, M., Raja, S., Holcomb, S., Molenar, J. V., Sherman, L., and Archuleta, C.: Observations of ammonia, nitric acid, and fine particles in a rural gas production region, Atmos. Environ., 83, 80-89, 2014.

Li, Y., Schichtel, B. A., Walker, J. T., Schwede, D. B., Chen, X., Lehmann, C. M., Puchalski, M. A., Gay, D. A., and Collett, J. L.: Increasing importance of deposition of reduced nitrogen in the United States, P. Natl. Acad. Sci. USA, 113, 5874-5879, 2016.

Li, Y., Thompson, T. M., Van Damme, M., Chen, X., Benedict, K. B., Shao, Y., Day, D., Boris, A., Sullivan, A. P., Ham, J., Whitburn, S., Clarisse, L., Coheur, P.-F., and Collett Jr., J. L.: Temporal and spatial variability of ammonia in urban and agricultural regions of northern Colorado, United States, Atmos. Chem. Phys., 17, 6197-6213, https://doi.org/10.5194/acp17-6197-2017, 2017.

Liu, F., Zhang, Q., Ronald, J. v. d. A., Zheng, B., Tong, D., Yan, L., Zheng, Y., and He, K.: Recent reduction in NO $\mathrm{x}$ emissions over China: synthesis of satellite observations and emission inventories, Environ. Res. Lett., 11, 114002, https://doi.org/10.1088/1748-9326/11/11/114002, 2016.

Liu, L., Zhang, X., Wang, S., Lu, X., and Ouyang, X.: A Review of Spatial Variation of Inorganic Nitrogen (N) Wet Deposition in China, PloS one, 11, e0146051, https://doi.org/10.1371/journal.pone.0146051, 2016.

Liu, L., Zhang, X., Xu, W., Liu, X., Lu, X., Wang, S., Zhang, W., and Zhao, L.: Ground Ammonia Concentrations over China Derived from Satellite and Atmospheric Transport Modeling, Remote Sensing, 9, 467, https://doi.org/10.3390/rs9050467, 2017a.

Liu, L., Zhang, X., Zhang, Y., Xu, W., Liu, X., Zhang, X., Feng, J., Chen, X., Zhang, Y., Lu, X., Wang, S., Zhang, W., and Zhao, L.: Dry Particulate Nitrate Deposition in China, Environ. Sci. Technol., 51, 5572, https://doi.org/10.1021/acs.est.7b00898, 2017b.

Liu, X., Duan, L., Mo, J., Du, E., Shen, J., Lu, X., Zhang, Y., Zhou, X., He, C., and Zhang, F.: Nitrogen deposition and its ecological impact in China: An overview, Environ. Pollut., 159, 2251-2264, https://doi.org/10.1016/j.envpol.2010.08.002, 2011.

Liu, X., Zhang, Y., Han, W., Tang, A., Shen, J., Cui, Z., Vitousek, P., Erisman, J. W., Goulding, K., and Christie, P.: Enhanced nitrogen deposition over China, Nature, 494, 459-462, 2013.

Liu, X., Vitousek, P., Chang, Y., Zhang, W., Matson, P., and Zhang, F.: Evidence for a Historic Change Occurring in China, Environ. Sci. Technol., 50, 505-506, 2015.

Liu, X., Xu, W., Duan, L., Du, E., Pan, Y., Lu, X., Zhang, L., Wu, Z., Wang, X., and Zhang, Y.: Erratum to: Atmospheric Nitrogen Emission, Deposition, and Air Quality Impacts in China: an Overview, Current Pollution Reports, 1-1, 2017.

Lu, X., Jiang, H., Liu, J., Zhang, X., Jin, J., Zhu, Q., Zhang, Z., and Peng, C.: Simulated effects of nitrogen saturation on the global carbon budget using the IBIS model, Scientific Reports, 6, 39173, https://doi.org/10.1038/srep39173, 2016.

Ma, J. Z., Beirle, S., Jin, J. L., Shaiganfar, R., Yan, P., and Wagner, T.: Tropospheric $\mathrm{NO}_{2}$ vertical column densities over Beijing: results of the first three years of ground-based MAXDOAS measurements (2008-2011) and satellite validation, Atmos. Chem. Phys., 13, 1547-1567, https://doi.org/10.5194/acp13-1547-2013, 2013. 
Meng, Z.-Y., Xu, X.-B., Wang, T., Zhang, X.-Y., Yu, X.L., Wang, S.-F., Lin, W.-L., Chen, Y.-Z., Jiang, Y.-A., and An, X.-Q.: Ambient sulfur dioxide, nitrogen dioxide, and ammonia at ten background and rural sites in China during 2007-2008, Atmos. Environ., 44, 2625-2631, https://doi.org/10.1016/j.atmosenv.2010.04.008, 2010.

Meng, Z. Y., Lin, W. L., Jiang, X. M., Yan, P., Wang, Y., Zhang, Y. M., Jia, X. F., and Yu, X. L.: Characteristics of atmospheric ammonia over Beijing, China, Atmos. Chem. Phys., 11, 61396151, https://doi.org/10.5194/acp-11-6139-2011, 2011.

Nowlan, C., Martin, R., Philip, S., Lamsal, L., Krotkov, N., Marais, E., Wang, S., and Zhang, Q.: Global dry deposition of nitrogen dioxide and sulfur dioxide inferred from space-based measurements, Global Biogeochem. Cy., 28, 1025-1043, 2014.

Ohara, T., Akimoto, H., Kurokawa, J., Horii, N., Yamaji, K., Yan, X., and Hayasaka, T.: An Asian emission inventory of anthropogenic emission sources for the period 1980-2020, Atmos. Chem. Phys., 7, 4419-4444, https://doi.org/10.5194/acp-7-44192007, 2007.

Olivier, J. G. J., Bouwman, A. F., Hoek, K. W. V. D., and Berdowski, J. J. M.: Global air emission inventories for anthropogenic sources of $\mathrm{NO}_{x}, \mathrm{NH}_{3}$ and $\mathrm{N}_{2} \mathrm{O}$ in 1990, Environ. Pollut., 102, 135-148, 1998.

Pan, Y. P., Wang, Y. S., Tang, G. Q., and Wu, D.: Wet and dry deposition of atmospheric nitrogen at ten sites in Northern China, Atmos. Chem. Phys., 12, 6515-6535, https://doi.org/10.5194/acp12-6515-2012, 2012.

Pfister, G., Emmons, L., Hess, P., Lamarque, J. F., Orlando, J., Walters, S., Guenther, A., Palmer, P., and Lawrence, P.: Contribution of isoprene to chemical budgets: A model tracer study with the NCAR CTM MOZART-4, J. Geophys. Res.-Atmos., 113, D05308, https://doi.org/10.1029/2007JD008948, 2008.

FRCGC (Frontier Research Center for Global Change): Regional Emission Inventory in Asia, available at: http://www.jamstec.go. jp/frsgc/research/d4/emission.htm (last access: 1 August 2017), 2007

Russell, A. R., Perring, A. E., Valin, L. C., Bucsela, E. J., Browne, E. C., Wooldridge, P. J., and Cohen, R. C.: A high spatial resolution retrieval of $\mathrm{NO}_{2}$ column densities from OMI: method and evaluation, Atmos. Chem. Phys., 11, 8543-8554, https://doi.org/10.5194/acp-11-8543-2011, 2011.

Russell, A. R., Valin, L. C., and Cohen, R. C.: Trends in OMI $\mathrm{NO}_{2}$ observations over the United States: effects of emission control technology and the economic recession, Atmos. Chem. Phys., 12, 12197-12209, https://doi.org/10.5194/acp-12-121972012, 2012.

Sahu, L., Sheel, V., Kajino, M., Gunthe, S. S., Thouret, V., Nedelec, P., and Smit, H. G.: Characteristics of tropospheric ozone variability over an urban site in Southeast Asia: A study based on MOZAIC and MOZART vertical profiles, J. Geophys. Res.Atmos., 118, 8729-8747, 2013.

Shi, Y., Cui, S., Ju, X., Cai, Z., and Zhu, Y.-G.: Impacts of reactive nitrogen on climate change in China, Scientific Reports, 5, 8118, https://doi.org/10.1038/srep08118, 2015.

Streets, D. G., Bond, T. C., Carmichael, G. R., Fernandes, S. D., He, D., Klimont, Z., Nelson, S. M., Tsai, N. Y., and Wang, M. Q.: An inventory of gaseous and primary aerosol emissions in Asia in the year 2000, J. Geophys. Res.-Atmos., 108, 30-31, 2003.
Sun, Q. and Wang, M.: Ammonia Emission and Concentration in the Atmosphere over China, Scientia Atmospherica Sinica, 1997.

Van Damme, M., Clarisse, L., Heald, C. L., Hurtmans, D., Ngadi, Y., Clerbaux, C., Dolman, A. J., Erisman, J. W., and Coheur, P. F.: Global distributions, time series and error characterization of atmospheric ammonia $\left(\mathrm{NH}_{3}\right)$ from IASI satellite observations, Atmos. Chem. Phys., 14, 2905-2922, https://doi.org/10.5194/acp14-2905-2014, 2014a.

Van Damme, M., Wichink Kruit, R., Schaap, M., Clarisse, L., Clerbaux, C., Coheur, P. F., Dammers, E., Dolman, A., and Erisman, J.: Evaluating 4 years of atmospheric ammonia (NH3) over Europe using IASI satellite observations and LOTOS-EUROS model results, J. Geophys. Res.-Atmos., 119, 9549-9566, 2014 b.

Van Damme, M., Clarisse, L., Dammers, E., Liu, X., Nowak, J. B., Clerbaux, C., Flechard, C. R., Galy-Lacaux, C., Xu, W., Neuman, J. A., Tang, Y. S., Sutton, M. A., Erisman, J. W., and Coheur, P. F.: Towards validation of ammonia $\left(\mathrm{NH}_{3}\right)$ measurements from the IASI satellite, Atmos. Meas. Tech., 8, 15751591, https://doi.org/10.5194/amt-8-1575-2015, 2015.

Walker, J. C., Dudhia, A., and Carboni, E.: An effective method for the detection of trace species demonstrated using the MetOp Infrared Atmospheric Sounding Interferometer, Atmos. Meas. Tech., 4, 1567-1580, https://doi.org/10.5194/amt-4-1567-2011, 2011.

Wang, S. W., Liao, J. H., Yu-Ting, H. U., and Yan, X. Y.: A Preliminary Inventory of $\mathrm{NH}_{3}-\mathrm{N}$ Emission and Its Temporal and Spatial Distribution of China, Journal of Agro-Environment Science, 2009.

Wang, S. W., Zhang, Q., Streets, D. G., He, K. B., Martin, R. V., Lamsal, L. N., Chen, D., Lei, Y., and Lu, Z.: Growth in $\mathrm{NO}_{x}$ emissions from power plants in China: bottom-up estimates and satellite observations, Atmos. Chem. Phys., 12, 4429-4447, https://doi.org/10.5194/acp-12-4429-2012, 2012.

Wang, W. X., Lu, X. F., Pang, Y. B., Tang, D. G., and Zhang, W. H.: Geographical distribution of NH3 emission intensities in China, Actaentiae Circumstantiae, 1997.

Warner, J. X., Dickerson, R. R., Wei, Z., Strow, L. L., Wang, Y., and Liang, Q.: Increased atmospheric ammonia over the world's major agricultural areas detected from space, Geophys. Res. Lett., 44, 2875-2884, https://doi.org/10.1002/2016GL072305, 2017.

Whitburn, S., Van Damme, M., Clarisse, L., Bauduin, S., Heald, C. L., Hadji-Lazaro, J., Hurtmans, D., Zondlo, M. A., Clerbaux, C., and Coheur, P. F.: A flexible and robust neural network IASINH3 retrieval algorithm, J. Geophys. Res.-Atmos., 121, 65816599, https://doi.org/10.1002/2016JD024828, 2016a.

Whitburn, S., Van Damme, M., Clarisse, L., Turquety, S., Clerbaux, C., and Coheur, P. F.: Doubling of annual ammonia emissions from the peat fires in Indonesia during the 2015 El Niño, Geophys. Res. Lett., 43, 11007-11014, https://doi.org/10.1002/2016GL070620, 2016b.

Wichink Kruit, R. J., Schaap, M., Sauter, F. J., van Zanten, M. C., and van Pul, W. A. J.: Modeling the distribution of ammonia across Europe including bi-directional surface-atmosphere exchange, Biogeosciences, 9, 5261-5277, https://doi.org/10.5194/bg-9-5261-2012, 2012.

Xia, Y., Zhao, Y., and Nielsen, C. P.: Benefits of China's efforts in gaseous pollutant control indicated by the bottom-up emissions and satellite observations 2000-2014, Atmos. Environ., 136, 43 53, https://doi.org/10.1016/j.atmosenv.2016.04.013, 2016. 
Xie, Y., Zhao, B., Zhang, L., and Luo, R.: Spatiotemporal variations of PM2.5 and PM10 concentrations between 31 Chinese cities and their relationships with $\mathrm{SO}_{2}, \mathrm{NO}_{2}, \mathrm{CO}$ and $\mathrm{O}_{3}$, Particuology, 20, 141-149, https://doi.org/10.1016/j.partic.2015.01.003, 2015.

Xu, W., Luo, X. S., Pan, Y. P., Zhang, L., Tang, A. H., Shen, J. L., Zhang, Y., Li, K. H., Wu, Q. H., Yang, D. W., Zhang, Y. Y., Xue, J., Li, W. Q., Li, Q. Q., Tang, L., Lu, S. H., Liang, T., Tong, Y. A., Liu, P., Zhang, Q., Xiong, Z. Q., Shi, X. J., Wu, L. H., Shi, W. Q., Tian, K., Zhong, X. H., Shi, K., Tang, Q. Y., Zhang, L. J., Huang, J. L., He, C. E., Kuang, F. H., Zhu, B., Liu, H., Jin, X., Xin, Y. J., Shi, X. K., Du, E. Z., Dore, A. J., Tang, S., Collett Jr., J. L., Goulding, K., Sun, Y. X., Ren, J., Zhang, F. S., and Liu, X. J.: Quantifying atmospheric nitrogen deposition through a nationwide monitoring network across China, Atmos. Chem. Phys., 15, 12345-12360, https://doi.org/10.5194/acp-15-123452015, 2015.

Xu, W., Song, W., Zhang, Y., Liu, X., Zhang, L., Zhao, Y., Liu, D., Tang, A., Yang, D., Wang, D., Wen, Z., Pan, Y., Fowler, D., Collett Jr., J. L., Erisman, J. W., Goulding, K., Li, Y., and Zhang, F.: Air quality improvement in a megacity: implications from 2015 Beijing Parade Blue pollution control actions, Atmos. Chem. Phys., 17, 31-46, https://doi.org/10.5194/acp-17-31-2017, 2017.
Zhao, C. and Wang, Y.: Assimilated inversion of NOx emissions over east Asia using $\mathrm{OMI} \mathrm{NO}_{2}$ column measurements, Geophys. Res. Lett., 36, 1-5, 2009.

Zhou, Y., Shuiyuan, C., Lang, J., Chen, D., Zhao, B., Liu, C., Xu, R., and Li, T.: A comprehensive ammonia emission inventory with high-resolution and its evaluation in the Beijing-TianjinHebei (BTH) region, China, Atmos. Environ., 106, 305-317, https://doi.org/10.1016/j.atmosenv.2015.01.069, 2015. 